\title{
Discussion on Internal Scientificity of Scientific Outlook on Development
}

\author{
Li Kang ${ }^{1} \&$ Chaofei $\mathrm{Li}^{1}$ \\ ${ }^{1}$ School of Political Science and Public Management, Southwest University, Chongqing, China \\ Correspondence: Li Kang, Southwest University, Chongqing 400715, China. E-mail: k1196351@163.com
}

Received: March 25, 2013 Accepted: April 11, 2013 Online Published: April 17, 2013

doi: 10.5539/ach.v5n2p142 URL: http://dx.doi.org/10.5539/ach.v5n2p142

\begin{abstract}
The party in power headed by Hu Jintao ever since the Sixteenth National Congress of the Communist Party of China put forward "scientific outlook on development". It then becomes an important guideline for Chinese economic and social development and is a significant strategic idea that we have to adhere to and carry out in order to develop socialism with Chinese characteristics. "Scientific outlook on development" covers a wide range of fields, such as, natural science, humanity science and social science, etc., constitutes a systematic scientific theory with profound ideological connotation and rigorous internal logic, and, in the meanwhile, is enriched and developed continuously in practice.
\end{abstract}

Keywords: scientific outlook on development, traditional outlook on development, sustainable outlook on development, scientificity

\section{General Characteristics of "Scientific Outlook on Development" as Possessed by Science}

Kant ever defined "science" as "Any theory is called science if it can become a system, namely, it becomes a whole of knowledge systemized in accordance with principles." There are mainly two standards to judge whether a theory has formed a scientific system. The first one is to judge whether it has a scientific and systematic world outlook and methodology; and the second one is to judge whether it proposes a series of interrelated basic views by taking into consideration of the central issues of the research.

1.1 Scientific Outlook on Development Is a Scientific System with Abundant Content and Rigorous Logic and Has the Characteristics of Systematicness

Scientific outlook on development is a complete and scientific system and has the characteristics of systematicness that scientific knowledge has. The Secretary General of CPC Hu Jintao mentioned in the Report of The 17th National Congress of CPC, the first principle of scientific outlook on development was development; the core was human orientation; the basic requirement was overall, coordinated and sustainability; the fundamental method was to make overall plans an take all factors into consideration. As a systematic scientific theory system, first of all, scientific outlook on development takes the dialectical materialism and historical materialism of Marxism as its foundation of scientific world outlook and methodology; then, it proposes a series of basic views by centering around the central issues in constructing socialism with Chinese characteristics: one core, namely human orientation; two value objectives, namely, all-round development of the economic society and all-round development of human; three development ideas, namely, overall, coordinated and sustainable development; the construction pattern of four-in-one, namely, economic construction, political construction, cultural construction and social construction; five development strategies of overall development, namely, overall development of urban and rural areas, overall regional development, overall economic and social development, overall harmonious development of human and the nature and overall domestic development and opening to the outside world. Thus, considering the systematicness of scientific knowledge, scientific outlook on development has the feature of systematicness that is necessary to become science.

1.2 Scientific Outlook on Development Reveals the General Rule of Development of the Economic Society and Has the Characteristics That Corresponds with the Objective Regularity

Science is to discover a phenomenon, to find out the internal necessary connection that generates the phenomenon and then to reveal its regular activities. The proposal of scientific outlook on development marks that cognition of the Communist Party of China in the rule of construction of socialist, the rule of human social 
development, the rule of contemporary world economic development and the rule of CPC holding power has attained a brand-new height, symbolizes that Marxism and the latest Chinese national situation have got perfect combination and is the latest theoretical achievement of sinicization of Marxism.

The objective regularity of scientific outlook on development is mainly manifested in the following two aspects. On one hand, scientific outlook on development corresponds with the general rule of human social development. Scientific outlook on development puts forward the developmental idea with the core of human orientation based on the tenet of the CPC to serve the people wholeheartedly, fulfills the overall development of human being, and shows care for the immediate interests of the public at any moment, all for people and for all of people, which corresponds with the requirement of development of the contemporary times and is a common pursuit by people from all nationalities in the world. In addition, it also suggests that the proposal of establishing a harmonious world and persistently walking towards a peaceful development path is a common wish and pursuit of all people from all over the world, and, thus, corresponds with the general rule of human social development. On the other hand, the scientific outlook on development corresponds with the general rule of contemporary world economic development. The tendency of economic globalization in the contemporary world is becoming more and more obvious and communication and cooperation between different countries is also becoming more and more extensive. With in-depth development of economy, a series of problems in development are brought about, which need to be urgently resolved. Under such a background of world economic development, scientific outlook on development puts forward the natural development of human and the world and the harmonious development of economy and society and of human and the society. This not only focuses on development of economy and the society, but also bears in mind overall development of human. Scientific outlook on development adheres to the five overall considerations and overall consideration of the relationship between domestic development and opening to the outside world is exactly correct summarization of the rule of economic development under the contemporary background of integration of world economy. Scientific outlook on development surpasses national boundaries and ideology and not only reveals the common rule of human development in the whole world, but also reveals the general rule of contemporary world economic development, so it has the characteristics of objectiveness and regularity, which is further termed as scientificness.

\subsection{Scientific Outlook Is a Scientific Theory Testified by Practice and Has the Characteristics of Realistic Practicalness}

Proposal and establishment of a theoretical system not only needs mature content, but also needs to possess the soil to convert from theory to reality. The key to judge whether the theory is entitled to become science is to see whether it is able to endure test of reality and be verified by reality. This requires theory to serve for reality and to become a guide to action for guiding development of practice.

Scientific outlook on development is exactly a scientific theory that stands up to the test of practice and guides practice. It is a scientific solution for both of international and domestic conditions we encounter at present. In the large international environment, we are faced up with the urgent requirement to pursue peace and development and to enhance the overall national strength. It is the key to realize the great rejuvenation of the Chinese nation how to coexist peacefully, cooperate closely and make progress together with all nations all over the world at the time when we realize our own prosperity and strength and peaceful rise. Scientific outlook on development sticks to human orientation, adheres to overall consideration, establishes a harmonious socialist society and a harmonious world, which is exactly a kind of overall, coordinated and sustainable development, a kind of peaceful development approach which pays attention not to damaging development of other countries at the time of realizing its own prosperity. Thus, it has gained favorable comment and recognition from all over the world, has been widely promoted, and, is a kind of scientific theory which has been proved by practice. In the small domestic environment, we are faced up with such realistic problems as large income gap, serious environmental pollution, insufficient social security and imbalance between regional and urban and rural development. Thus, scientific outlook on development adheres to human orientation, fulfills overall development of human, takes overall consideration of urban and rural development and regional development, gives consideration to fairness and justice and, thus, gains recognition and support of the vast majority of people. Practice is the unique standard that tests the truth, while scientific outlook on development is exactly a scientific theoretical system that has been proved by practice and becomes a guidance principle and guide to action for us to construct socialism with Chinese characteristics, build a well-off society and finally realizes the great rejuvenation of Chinese nation.

2. "Scientific Outlook on Development" Is Introspection and Surpassing of the Traditional Outlook on Development throughout Chinese History

\subsection{Connotation and Limitation of the Traditional Outlook on Development}

As a sort of industrial civilization concept, the essence of the traditional outlook on development is the 
development outlook centered with economy, which sees the industrialization process of a nation as the major characteristics and sign of modern civilization. It regards growth of industrial output as the unique scale and indicator to measure social development. The traditional outlook on development blindly pursues economic growth and growth of material wealth, excessively goes after growth of GDP and equals development as economic growth. The development mode under the guidance of this development outlook is high consumption, high investment, high pollution, high emission, and low efficiency, all aimed for development. Although this kind of development outlook, indeed, facilitated rapid economic development of all nations at the primary stage of industrialization during a particular historical period, its drawbacks were also quite obvious. With continuous development in depth and breadth of modernization progress, contradictions and drawbacks caused by the traditional outlook on development became more and more prominent. At the time when it stimulated great economic development, economic prosperity and continuous increase in industrial output, it also brought about a series of problems, such as, environmental pollution, resource exhaustion, ecological crisis, fairness imbalance and prominent and acute social contradiction, which were more and more highlighted and became a bottleneck that constrained continuous development of economy. Transformation and innovation of the traditional outlook on development has become a common sense in all countries. It is urgently wished to change the development concept and to seek for a kind of persistent, scientific and overall development mode. Thereof, the sustainable outlook on development emerged just as the times required.

\subsection{Connotation and Limitation of "Sustainable Outlook on Development"}

Before the sustainable outlook on development came into being, it was widely believed that development of the world and growth of economy were unlimited, and "Limitlessness of growth" ever became a mainstream development idea in the society. The Club of Rome ever published a report entitled "Limits to Growth" in the 1970s, in which this club refuted the viewpoint of limitlessness of growth with quite a lot of scientific data. Since growth was not limitless, then for consideration of human survival and development, the idea of sustainable outlook on development was put on the agenda naturally.

The United Nations defines "sustainable development" as "The development that not only meets with the need of contemporary people, but also pays attention not to impair the ability of the descendants to satisfy their need." Compared with the traditional outlook on development, sustainable outlook on development is a progress and surpassing, which not only adheres to development, but also focuses on how to develop and the development idea of why to develop. It was put forward on the basis of criticizing and referring to the traditional outlook on development, which held the view that development should not be purely economic development or growth of wealth, but should be overall, coordinated and sustainable development of economy and the society. Its limitation is that it has failed to explicitly put forward "human orientation", but deepened from purely economic development to common development of economy and the society, namely, "development = economy + society". Compared with the scientific outlook on development, sustainable outlook on development merely emphasizes the relationship between economic development and environmental protection and merely focuses on harmony and unification of human and the nature, but ignores overall, coordinated and sustainable development of the society and ignores the overall development of economy and politics, economy and the society and economy and culture. What's more, it mainly lays insufficient emphasis on development of human, and focuses more on the nature.

\subsection{The Sustainable Development Idea of Deng Xiaoping under Constraint of the Objective Reality}

At the preliminary stage of the reform and opening up in China, Deng Xiaoping theory was the main theoretical guidance that guided our work. The development idea of Deng Xiaoping is innovation and improvement of the traditional outlook on development and is embodiment that sticks to sustainable outlook on development. It not only gives consideration to the economic development, but also takes into account of social development and lays special stress on sustainability and comprehensiveness of development. On one hand, he put forward the development idea of "economic construction as the center", "emancipation and development of productivity", and "Development is the absolute principle", which became the basic ideas and guiding thought that guided the reform and opening up and construction of socialism with Chinese characteristics at the preliminary stage of the reform and opening up. Under direction of this development idea, the new China changed the situation of poverty and backwardness. Instead, the economy was rapidly developed, the GDP maintained a high-speed growth for many years which created the historical record of growth speed in China, and remarkable achievements were achieved in the economic growth. On the other hand, Deng Xiaoping put forward the ideas "Poverty does not mean socialism", "We have to eliminate polarization and encourage the rich to lead the poor and finally realize the common prosperity". Although Deng Xiaoping had not directly put forward or applied the sustainable outlook on development, both of its ideological connotation and essence were a kind of sustainable 
development idea.

In the process of construction of socialist modernization with Chinese characteristics, the development idea of Deng Xiaoping has made noticeable contributions and is the theoretical footstone for us to put forward the scientific outlook on development today. Nevertheless, the development idea of Deng Xiaoping came under constraint of realistic conditions, especially constraint of social and economic conditions at the preliminary stage of the reform and opening up in China, so it had to adapt to both the international and domestic environment at that time. Prior to the reform and opening up, the negative impacts of the ten chaotic years had not been totally wiped off, so the economic stagnation existed for a long time, the materials were in great deficiency, the material life of people was trapped into extreme hardship and the problem of food and clothing became the biggest problem that affected Chinese development. Under such circumstance, it is true that we had profound reflection and took control on such in-depth problems as the essence of development, the development path, the development mode and the development idea, but under the constraint of objective conditions, in order for the economic growth to still firstly ensure a high development speed, it would, of course, inevitably unlikely to fundamentally resolve the negative problems brought about by economic development. In the process of development, all local governments excessively pursued GDP, which led to excessive consumption of resources, reduced efficiency of utilization and serious pollutant discharge. The current ecological environment and status of resources were unable to endure such enormous pressure, and would necessarily cause the economic development to severely break away from the pace of social development. The development practice of socialism with Chinese characteristics and the development idea of Deng Xiaoping have not got perfect combination. Today, the scientific outlook on development we have put forward is innovation and improvement of the development theory of Deng Xiaoping and is a brand-new development theory that more fits with the objective rule of development.

\section{To Carry out and Implement the Scientific Outlook on Development, Stick to "Five-in-One" and Push forward Social Construction of China}

The scientific outlook on development carries forward the positive and reasonable factors in the sustainable outlook on development and forms a brand-new theory according to the new situations and new problems encountered in the process of Chinese social development. This outlook not only focuses on development of the society, but also more concentrates on emancipation and development of human. It can be said that, "Scientific outlook on development $=$ economy + society + man". Compared with the sustainable outlook on development, the scientific outlook on development focuses more on the value of man and human orientation and its content is more scientific and complete.

It was definitely proposed by the former Chinese President Hu Jintao in the Report of the 17th National Congress of CPC to construct "ecological civilization" of socialism. Construction of the material civilization, spiritual civilization and political civilization of socialism can not go without ecological civilization. The Report of the 18th National Congress of CPC further emphasized the important position of construction of ecological civilization. It further incorporated construction of ecological construction with the four in one of economic construction, political construction, cultural construction and social construction into "five in one", which becomes the overall pattern in development of the career of socialism with Chinese characteristics. It is impelled to say that this is an enormous progress and is further enrichment, improvement, innovation and development of the scientific outlook on development.

The spiritual essence of the scientific outlook on development is emanation of thought, coming down to earth, keeping pace with the times and staying realistic and pragmatic. In-depth implementation of the scientific outlook on development is to continuously emancipate the thought, come down to earth, keep pace with the times, stay realistic and pragmatic, and continuous theoretical innovation and practical innovation. "Practice and development are of no bounds, cognition in a truth is of no bounds and theoretical innovation is also of no bounds." The scientific outlook on development constantly improves the theoretical system of socialism with Chinese characteristics, insists that the system of socialism with Chinese characteristics is unwavering, unswervingly takes the path of socialism with Chinese characteristics and makes great efforts and struggles for striving for the new victory of socialism with Chinese characteristics and building a well-off society. In one word, the scientific outlook on development is a kind of scientific theory that is established on the basis of an objective fact and that profoundly reveals the rule of economic and social development, has rigorous and logical structural system and is able to endure the test and verification of the practice. Whether in terms of its own characteristics, or in terms of its comparison with other outlooks on development, the scientific outlook on development is, so far, the most scientific, the latest and the most comprehensive development idea. 


\section{References}

CCCPC Party Literature Research Office. (2005). Important Selected Literature since the Sixteenth National Congress of the Communist Party of China (Vo. 1).

Feng, Z. (2004). Building the Conception of Scientific Development and Realizing the Sustainable Development. China Soft Science, (1).

$\mathrm{Hu}$, J. (2009). To Try to Improve the Implementing of the Scientific Outlook on Development to a New Level. Seeking Truth, (1).

Immanuel, K. (2003). Metaphysical Foundations of Natural Science. Shanghai: Shanghai People's Publishing House, 2.

Wu, H., \& Liu, J. (2008). Discussion on Scientificity of Scientific Outlook on Development. Academy of Marxism, (10).

Zhang, L. (2004). The View of Science Development and the Development of Socialism with Chinese Characteristics. Journal of Ideological \& Theoretical Education, (2). 